\title{
THE IMPACT OF SHIRORO DAM PROJECT ON PRODUCTIVITY AND LIVELIHOOD DIVERSIFICATION OF RURAL FISHERFOLKS IN NIGER STATE, NIGERIA
}

\author{
Oladimeji, Y. $\mathbf{U}^{1^{*}}$, Abubakar, B. AY ${ }^{2}$., Abdulsalam, $Z^{1}$. \\ ${ }^{1}$ Department of Agricultural Economics, Ahmadu Bello University, Zaria-Nigeria \\ ${ }^{2}$ Post Graduate Program, Department of Agricultural Economics, Ahmadu Bello University, Zaria-Nigeria \\ *Corresponding author’s e-mail: yusuf.dimeji@ yahoo.com ; +234803222000
}

\begin{abstract}
The interdependence of water, food and energy are widely recognized as important drivers of socioeconomic development. The objective of the study was to assess the impact of Shiroro Dam Project (SDP) on productivity and livelihood diversification of rural fisherfolks in Niger state, Nigeria. Primary data were collected from the fisherfolks with the aid of structured questionnaires. A multistage sampling procedure was used to select 363 fisherfolks from two LGAs, twelve villages and 1,210 sample frames. Two hundred and sixty (267) fisherfolks who are non-beneficiaries of SDP were also selected as counterfactual to examine the impact. The data were analyzed using descriptive statistics, Tobit regression, Propensity Score Matching (PSM) and the Local Average Treatment Effect (LATE) models. Result revealed that fishery activities were the most important source of income $(68.3 \%)$ among the fisherfolks. The coefficients of length of fishing gears (-0.400), capacity of outboard engine (-0.005), household size (0.008), credit accessed for fishery (0.052) and per capita expenditure (0.306) were statistically significant factors influencing the extent of livelihood diversification of Shiroro dam fisherfolks. There was statistically significant difference between the mean income of fisherfolks ( $\$ 56,119.06$ per annum) who benefitted from SDP and counterfactual ( $\$ 37,876.80$ ). Similarly, the results of impact of SDP on productivity of fisherfolks revealed that the treatment effect on the treated (ATT) increases productivity of the benefitted fisherfolks by $2.8273(38.1 \%)$, that ATU had a significant and positive impact (0.1282) on productivity, and the average effect of the treatment (ATE) for SDP fisherfolks has a positive difference of 0.6654 compared to the treated category. Fisherfolks should form a formidable social organization to benefit from economy of bulk purchase of farm inputs especially fishing gears and outboard engine, farm advisory services, increased access to credit, and access to other modern fishing techniques.
\end{abstract}

Keywords: Fisherfolks, impact, income, Shiroro dam project, Nigeria

http://dx.doi.org/10.21776/ub.agrise.2020.020.3.2

Received 10 February 2020

Accepted 11 April 2020

Available online 29 July 2020

\section{INTRODUCTION}

The interdependence of water, food and energy are widely recognized as important drivers of socioeconomic development. This importance is embedded in the United Nations 2030 Agenda for Sustainable Development Goals Report as Nigerian population is expected to increase to 262, 599000 people by 2030 ((UN SDG, 2016; ICSU-ISSC, 2015, UNDESA, 2015). The economic benefits of dams outweigh the costs, thus providing rationale for construction of dams around the world (Philip et al., 2008). Dams are important means of meeting water; energy and food need in the long-term, strategic investments with many additional benefits. Some of these benefits include projects or regional development, employment generation, and fostering of local industry (World Commission on Dam, 2000). Impacts of dams can be involuntarily imposed on rural farming households whose livelihoods are dependent on riverine resources through contributions to economic growth while the services they provide may come at a cost (Skinner et al., 2009, Oladimeji and Abdulsalam, 2014).

Similarly, large dams by increasing irrigation and hydroelectricity production, can stimulate development and reduce poverty has led developing countries and international agencies such as the World Bank to undertake major investments in dam construction. By implication, dams generated $19 \%$ of the world's electricity supply and irrigated over 
$30 \%$ of the 271 million hectares irrigated worldwide (World Commission on Dam, 2000). Dams often transformed surrounding communities positively (Skinner et al., 2009). Irrigation practice across the world is vital to successful green revolution all year round to achieving sustainable development goals in food security, socio-economic and rural development. However, irrigation practice in Nigeria has not achieved the set goals despite the huge investment involved. Moreover, the level of investment and abundant water resources ought to have expedited the goals of food self-sufficiency and socio-economic development in the country (Bashir Adelodun and Kyung-Sook Choi 2018).

Non-farm earnings account for a considerable share of farm household income in rural farming Africa household (Reardon, 1997; Barrett et al., 2001). Rural farm household diversify into non-farm income earning due to the activities diminishing or time-varying returns to labour or land, market failures (example for credit) or frictions, risk management, and to be able to cope with adverse shocks.

Based on the foregoing, policy makers at national regional and household levels should focus on increasing agricultural productivity and farm income so as to attain food self-sufficiency. Although, substantial resources have been spent on agricultural research and extension to alleviate food shortage in the nation, issues related to off or nonfarm diversification with regards to dam should be adequately looked into. In spite of this fact, farmers are engaged in a variety of off and / or non-farm activities to diversify their income with a view to feed and sustain themselves during crop failures. Moreover, the contribution made by livelihood diversification to rural livelihoods is significant and has often been ignored by policy makers who have chosen to focus their activities on agriculture (Ellis, 1998 Oladimeji et al., 2015).

In developing countries fish is an important source of both food and income to many people. According to FAO (2012), fish contribute more than $60 \%$ of the world supply of protein, especially in the developing countries. The global fish production was estimated to about 171 million tonnes in 2016, valued at USD 362 billion. Between 1961 and 2016, the average annual increase in global food fish consumption, $3.2 \%$ outpaced population growth, $1.6 \%$ and exceeded that of meat from all terrestrial animals combined, $2.8 \%$ (FAO, 2018). In per capita terms, food fish consumption grew from $9.0 \mathrm{~kg}$ in 1961 to $20.2 \mathrm{~kg}$ in 2015 , at an average rate of about 1.5 percent per year. New Partnership for African Development (2005) state that, in Africa the fisheries sector provides income for over 10 million people engaged in fish production, processing and trade. Fish has also become a leading export commodity for Africa with an annual export value over USD 2.7 billion (FAO, 2007, FAO, 2018).
Policy makers and researchers have often ignored the contribution made by rural livelihood diversifications focusing attention on agriculture (Carswell, 2000) especially artisanal fishery. It is pertinent to note that research works on the impact of dam on productivity and livelihood diversification of rural fish farming household are scanty. This study therefore examines the impact of Shiroro dam on productivity and livelihood diversification of rural fisherfolks. Consequently, the study seeks to provide answers to the following research questions:

a. what are the level of livelihood diversification among artisanal fisherfolks?

b. which factors influence the extent of livelihood diversification of fisherfolks?

c. are there impact of Shiroro dam project on the livelihood diversification?

d. are there impact of Shiroro dam project on the productivity of fisherfolks?

e. what are the constraints encountered by the rural fisherfolks in the study area?

\section{METHODOLOGY}

\section{Description of the Study Area}

This study was conducted in Shiroro, Munya and Gurara Local Government Areas (LGAs) of Niger state. The State is located between Latitude $8^{0} 22^{\prime} \mathrm{N}$ and $11^{\circ} 30^{\prime} \mathrm{N}$ and Longitude $3^{\circ} 30^{\prime} \mathrm{N}$ and $7^{0} 20^{\prime} \mathrm{E}$ and covers a land area of about 74,244 sq. km, or about $8 \%$ of Nigeria's total land area. The climate, soil and hydrology of the state permit the cultivation of most of Nigeria's staple crops such as maize, yam, rice millet, sorghum, and allows sufficient opportunities for grazing, fresh water fishing and forestry development.

Specifically, the Shiroro hydropower reservoir is a storage based hydroelectric facility located in Niger State at the Shiroro Gorge with approximately between Latitude $9^{0} 46^{\prime} 35$ and $10^{\circ} 08^{\prime} 36 \mathrm{~N}$ and Longitude $6^{0} 50^{\prime} 51$ and $6^{0} 53^{\prime} 14 \mathrm{~N}$. It is located approximately $90 \mathrm{~km}$ southwest of Kaduna on River Dinya. The facility has an installed capacity of 600 MW (Kolo, 1996). The reservoir has a surface area of about $320 \mathrm{~km}^{2}$ with a maximum length of $32 \mathrm{~m}$ and a total storage capacity of 7 billion $\mathrm{m}^{3}$ of water (Usman and Ifabiyi, 2012). About $70 \%$ of inflows into the reservoir are from river Kaduna, with lateral contributions from rivers Dinya, Guni, Sarkin-Pawa, Erena and Muyi. Annual temperature around the reservoir varies between 27 and $35^{\circ} \mathrm{C}$. (Abayomi et al., 2015)

\section{Method of data Collection and Sampling Procedure}

Primary data was collected in 2019 fishery season, with the aid of a structured questionnaire and trained field enumerators for the study. Information 
collected includes: socio-economic characteristics, livelihood diversification activities, fishery inputs such as size of canoes in meters; length of fishing gears (nets) in meters; fuel gasoline and diesel oil in litres; number of plastic container, hand paddlers and baits and capacity of outboard engine in horse power.

A multistage sampling procedure was used to obtain the sampled respondents. Two Local Government Areas (LGAs) Shiroro and Muya out of the twenty-five LGAs in Niger state were purposefully selected because of location of Shiroro dam in the vicinity of villages in the two LGAs and concentration of fisherfolks in the villages. The list of beneficiary villages was listed and a total of a dozen villages were randomly selected through balloting from the two LGAs proportionate to size. The list of fisherfolks in each village was compiled and $30 \%$ of the sampling frame $(1,210)$ was randomly selected through balloting totaling 363 fisherfolks.

On the other hand, two hundred and sixty (267) fisherfolks who are non-beneficiaries of Shiroro dam fishery expedition but engage in fishing nearby communities in Kebbi and Kwara states with similar socio-economic characteristics were randomly selected from a sample frame of nine hundred and sixty two (962) fisherfolks (Oladimeji, 2018) as counterfactual to examine the impact of the dam on productivity of the fisherfolks.

\section{Analytical techniques}

Descriptive statistics and the mean of income shares approach were used to estimate the level of livelihood diversification by the fisherfolks in Niger state, Nigeria. The general mean of income shares (MIS) formula is given as:

$$
M S_{i}=\frac{\sum_{h=1}^{n} y_{i h} / Y_{h}}{n}
$$

(Bernard et al., 2014; Oladimeji et al., 2018)

Where $I=$ the income source (naira, $\mathrm{N}$ ), $\mathrm{Y}=$ total Income (naira, $\mathrm{N}$ ), $y=$ income from particular activity (naira, $N$ ), the household (number of persons), $n=$ the number of fisherfolks. Equation (1) was applied in this study as: The sum of total household income (THI) is given as:

$$
\begin{aligned}
\text { THI }= & \sum_{j=1}^{16} Y_{j} \quad \ldots \ldots \ldots \text { (2) } \quad(\text { Schw } \\
& \text { Zeller, 2005; Bernard et al., 2014) }
\end{aligned}
$$

Where: $\mathrm{THI}=$ Total Household Income, thus income coming from all sources $j$

$j=1,2,3,4 \ldots .16$, fish, off-fish and non-fish income.

Factors influencing diversification of fisherfolks to non-fishery activities were determined using Tobit model. This was measured by the share of fishery income (from all activities) in total fisherfolks' income. The diversity index of zeros indicated no diversification in the dependent variable for some respondents necessitated the use of the censored and truncated Tobit regression. Thus:

$Y_{i}^{*}=\sum \mathrm{X}_{\mathrm{i}} \beta+\mu_{\mathrm{i}}$

Where: $Y_{i}^{*}$ is the vector of variables indicating the dependent variables in the model;

$Y_{i}=P_{i}=\left(\mathrm{X}_{\mathrm{i}} \beta, \mu_{\mathrm{i}}\right)$, if $\mathrm{P}_{\mathrm{i}}>\mathrm{P}_{\mathrm{i}}^{*} \ldots \ldots$ (4)

$0=\left(X_{i} \beta, \mu_{i}\right)$, if $P_{i} \leq P_{i}^{*}$

$\mathrm{i}=1,2 \ldots, 363$

(Equations 3 -5: Tobin, 1958 adopted by Schwarze and Zeller, 2005; Bernard et al., 2014; Femi and

Adelomo, 2016, Oladimeji, 2018)

Where: $Y_{i}^{*}$ is the vector of variables indicating the share of income in fishery from total household income. $\beta$ is a vector of unknown co-efficient and $\mu \mathrm{i}$ is an independently distributed error term. $\mathrm{Xi}$ is a vector of explanatory variables stated explicitly in equation 6 below. $\mathrm{Pi}$ is the diversification depth or intensity defined as $(\mathrm{Z}-\mathrm{Yi}) / \mathrm{Z}$ and $\mathrm{Pi}^{*}$ is the diversification intensity, when the diversification line $(\mathrm{Z})$ equals the $\mathrm{Z}-\mathrm{Yi}$. The model was estimated using maximum likelihood estimation (MLE) procedure.

$\mathrm{Y}_{\mathrm{i}}=\beta_{0}+\beta_{1} \mathrm{X}_{1}+\beta_{2} \mathrm{X}_{2}$

$+\beta_{3} X_{3}+\beta_{4} X_{4}+\beta_{5} X_{5}+\beta_{6} X_{6}+\beta_{7} X_{7}+\beta_{8} X_{8}+\beta_{9} X_{9}$

$+\beta_{10} X_{10}+\beta_{11} X_{11}+\varepsilon_{i}(6)$

(Equation 6 adopted from Oladimeji, 2018)

Where: $X_{1}=$ size of canoes in meters; $X_{2}=$ length of fishing gears (nets) in meters; $X_{3}=$ capacity of outboard engine in horse power; $\mathrm{X}_{4}=$ level of investment, $(\mathrm{N}) ; \mathrm{X}_{5}=$ age (years); $\mathrm{X}_{6}=$ household size (number of persons per fisherfolks); $X_{7}=$ level of education (years); $\mathrm{X}_{8}=$ credit accessed (Naira); $\mathrm{X}_{9}=$ cooperative society (years); $\mathrm{X}_{10}=$ per capita expenditure (naira); $\mathrm{X}_{11}=$ market access (access $=1$ and 0 otherwise); $\beta_{0}=$ constant; $\beta_{1-} \beta_{11}$ are coefficients to be estimated and $\varepsilon=$ error term.

The challenge in impact evaluation based on observational data lies on the estimation of the counterfactual of the treated group based on the observations on the untreated group. This is because beneficiaries and non-beneficiaries are very unbalanced; that is, they are different socially, economically and psychologically. The impact of Shiroro dam project on the productivity of fisherfolks were achieved using the propensity score matching (PSM) and Local Average Treatment Effect (LATE) models. The method of propensity score matching (PSM) allows this matching problem to be reduced to a single dimension: that of the propensity score. PSM is defined as the conditional probability that a unit in the full sample receives the treatment, given a set of observed variables (Rosenbaum and Rubin, 1983). It entails computation using either Probit or Logit regression models. Thus: 
$p(X i)=P(d=1 \mid X i)$

Where $\mathrm{p}(\mathrm{Xi})$ is a consistent estimate of the propensity score evaluated at $\mathrm{Xi}$ while $\mathrm{Xi}$ were the variables used for the matching. $P$ score was estimated in the first stage and computed for each fisherfolks, the actual matching was carried out after $\mathrm{p}$ score was computed. The estimated propensity scores were used to estimate the Average Treatment Effect on the Treated (ATT) which was the parameter of interest as

$$
\delta=E\left(\frac{Y_{i}{ }^{1}-Y_{i}{ }^{0}}{D_{1}=1}\right)=E\left\{\frac{E\left(\frac{Y_{i}{ }^{1}}{D_{1}=1}, P\left(Z_{i}\right)\right)-E\left(\frac{Y_{i}{ }^{0}}{D_{1}=0^{\prime}} P\left(Z_{i}\right)\right)}{D_{1}=1}\right\}
$$

(Adopted from Idi et al., 2019)

Where: $P\left(Z_{i}\right)$ is the $P$-Score, $Y_{i}$ and $Y_{i}$ are the Shiroro dam fisherfolks beneficiaries and nonbeneficiaries respectively in the two counterfactual situations of receiving treatment (fisherfolks income benefit from Shiroro dam and nontreatment (non-beneficiaries of Shiroro dam. Two important properties of the PSM are the balancing property and conditional independence assumption (CIA). Testing for this property is important to ascertain if fisherfolks behavior within each group is actually similar. Related to the balancing of $\mathrm{P}$ score is CIA, which states that participating in fishery in Shiroro dam is random and uncorrelated with the fish output by the fisherfolks from the dam, once the set $\mathrm{f}$ observable characteristics, $Z$ are controlled. A further requirement is the common support condition, which requires that persons with the same values of covariates $Z$ have positive possibilities of being both beneficiaries and nonbeneficiaries (Heckman et al., 1999, Idi et al., 2019).

Furthermore, Heckman and Hotz, (1989), Hünermund and Czarnitzki, (2016) adopted from Imbens, and Angrist (1994), opined that Local Average Treatment Effect (LATE) estimator could be used to remedied the noncompliance problems experienced in estimation of the average treatment effect (ATE) for the population. LATE estimation was achieved using equation 9 below:

$E\left\lfloor Y^{1}-Y^{0} \mid T=C\right\rfloor=\frac{E\lfloor Y \mid Z=1\rfloor-E\lfloor Y \mid Z=0\rfloor}{E\lfloor D \mid Z=1\rfloor-E\lfloor D \mid Z=0\rfloor}$

T-statistics was used to determine the impact of Shiroro dam project on the livelihood diversification of fisherfolks. This was achieved to test whether there is significant difference between returns from fisheries from dam versus other activities of fisherfolks in the study area. It is a useful technique for comparing mean values of two sets of numbers. The formula is given by:

$$
t=\frac{\bar{X}_{1}-\bar{X}_{2}}{\sqrt{\frac{\sigma_{1}^{2}}{n_{1}}+\frac{\sigma_{2}^{2}}{n_{2}}}}
$$

(Adopted from Oladimeji et al., 2016)

Where: $\bar{X}_{1}=$ average return from fisheries for beneficiaries' fisherfolks ( $N) X_{2}=$ average return from non- beneficiaries' fisherfolks ( $), \sigma_{1}^{2}=$ variance from return of beneficiaries, $\sigma_{2}^{2}=$ variance for return from non-beneficiaries, $\mathrm{n}_{1}$ and $\mathrm{n}_{2}$ $=$ sample size of beneficiaries and non-beneficiaries fisherfolks.

\section{RESULTS AND DISCUSSION Classification of Livelihood Diversification}

The shares of incomes from different livelihood activities are summarized by sectors in Table 1 . Although the activities were important sources of income for all the fisherfolks sampled, fishing activities were the most important source of income $(68.3 \%)$ which is in tandem with study of Oladimeji (2018) on determinants of livelihood diversification among rural artisanal fisherfolks in north-central and north-western Nigeria. However, off-fish activities which accounted for $22.66 \%$ of total fisherfolks' income were largely made up of crop production which constitutes about $65.5 \%$ of offfish sectorial activities. Others such as livestock / poultry $(2.98 \%)$, agric. wage labour $(2.26 \%)$ and agriculture input or output items $(1.49 \%)$ were also captured but of lesser important.

\section{Factors Influencing Extent of Livelihood Diversification among Fisherfolks}

Table 2 shows the factors influencing extent of livelihood diversification among Fisherfolks in Shiroro dam. In the regression model, the coefficients of length of fishing gears (-0.400), capacity of outboard engine (-0.005), household size (0.008), credit accessed for fishery (0.052) and per capita expenditure (0.306) were statistically significant factors influencing the extent of livelihood diversification of Shiroro dam fisherfolks. 


\begin{tabular}{|c|c|c|c|c|}
\hline Activities & $\begin{array}{c}\text { Amount per } \\
\text { season }\end{array}$ & $\%$ & $\begin{array}{c}\text { Sector } \\
\text { ranking }\end{array}$ & Pooled ranking \\
\hline \multicolumn{5}{|l|}{ Fishery income } \\
\hline Share of fishery income & 0.684 & & & \\
\hline actual fishing & 73.007 .60 & 43.51 & $1^{\text {st }}$ & $1^{\text {st }}$ \\
\hline canoe building & $18,005.50$ & 10.73 & $2^{\text {nd }}$ & $3^{\text {rd }}$ \\
\hline canoe transportation & $11,530.91$ & 6.87 & $3^{\text {rd }}$ & $4^{\text {th }}$ \\
\hline fish processing \& marketing & $6,980.04$ & 4.16 & $4^{\text {th }}$ & $6^{\text {th }}$ \\
\hline fish net making \& repairs & $2,620.00$ & 1.56 & $5^{\text {th }}$ & $11^{\text {th }}$ \\
\hline engine services & $2,600.75$ & 1.55 & $6^{\text {th }}$ & $12^{\text {th }}$ \\
\hline sub-total & $114,744.80$ & 68.38 & & \\
\hline \multicolumn{5}{|l|}{ Off-fish income } \\
\hline Share of fishery income & 0.227 & & & \\
\hline crop production & $25,005.00$ & 14.9 & $1^{\mathrm{st}}$ & $2^{\text {nd }}$ \\
\hline Livestock / poultry & $5,003.06$ & 2.98 & $2^{\text {nd }}$ & $7^{\text {th }}$ \\
\hline agric. wage labour & $3,800.05$ & 2.26 & $3^{\text {rd }}$ & $8^{\text {th }}$ \\
\hline agric. input or output marketing & $2,500.08$ & 1.49 & $4^{\text {th }}$ & $13^{\text {th }}$ \\
\hline apiculture / beekeeping & $1,720.90$ & 1.02 & $5^{\text {th }}$ & $14^{\text {th }}$ \\
\hline sub-total & $38,029.09$ & 22.66 & & \\
\hline \multicolumn{5}{|l|}{ Non-farm income } \\
\hline Share of fishery income & 0.089 & & & \\
\hline commercial motorcycle & $7,540.05$ & 4.49 & $1^{\mathrm{st}}$ & $5^{\text {th }}$ \\
\hline wood carving / carpentry & $3,650.00$ & 2.18 & $2^{\text {nd }}$ & $9^{\text {th }}$ \\
\hline non-farm rural wage & $2,800.00$ & 1.67 & $3^{\text {rd }}$ & $10^{\text {th }}$ \\
\hline remittance \& gifts & $1,050.00$ & 0.63 & $4^{\text {th }}$ & $15^{\text {th }}$ \\
\hline sub-total & $15,040.05$ & 8.96 & & \\
\hline Total & & 100 & & \\
\hline
\end{tabular}

Source: Field survey, 2019.

Table 2. Estimate of factors influencing extent of livelihood diversification of fisherfolks

\begin{tabular}{|c|c|c|c|c|c|}
\hline Variable & Parameter & Coefficient & Std Error & T-value & $\mathrm{P}>/ / \mathrm{Z} / /$ \\
\hline Constant & $\beta_{0}$ & $0.203 *$ & 0.115 & 1.76 & 0.062 \\
\hline size of canoes & $\beta_{1}$ & 0.076 & 0.106 & 0.72 & 0.209 \\
\hline length of fishing gears & $\beta_{2}$ & $-0.400 * *$ & 0.196 & -2.04 & 0.037 \\
\hline capacity of outboard engine & $\beta_{3}$ & $-0.005^{* * *}$ & 0.001 & -5.00 & 0.000 \\
\hline investment & $\beta_{4}$ & 0.002 & 0.002 & 1.00 & 0.168 \\
\hline Age & $\beta_{5}$ & -0.105 & 0.300 & -0.35 & 0.421 \\
\hline household size & $\beta_{6}$ & $0.008 * * *$ & 0.003 & 2.67 & 0.001 \\
\hline level of education & $\beta_{7}$ & 0.016 & 0.025 & 0.65 & 0.250 \\
\hline credit accessed for fishery & $\beta_{8}$ & $0.052 *$ & 0.028 & 1.87 & 0.051 \\
\hline cooperative society & $\beta_{9}$ & -0.006 & 0.007 & -0.85 & 0.163 \\
\hline per capita expenditure & $\mathrm{B}_{10}$ & $0.306^{* *}$ & 0.148 & 2.07 & 0.030 \\
\hline market access & $\mathrm{B}_{11}$ & -0.001 & 0.001 & -1.06 & 0.156 \\
\hline \multicolumn{6}{|l|}{ Diagnostic statistics } \\
\hline Number of observation & 363 & & & & \\
\hline Log likelihood ratio & -72.09 & & & & \\
\hline Restricted log likelihood ratio & -91.01 & & & & \\
\hline Chi square $(\chi 2)$ & 14.07 & & & & \\
\hline Pseudo $\mathrm{R}^{2}$ & 0.185 & & & & \\
\hline Probability $>\mathrm{Chi}^{2}$ & 0.000 & & & & \\
\hline
\end{tabular}

Source: Field survey, 2019; Note: $* * * \mathrm{P}<0.01$ and $* *<0.05$ level of probability.

The coefficients of length of fishing gears ($0.400)$ and capacity of outboard engine (-0.005) were statistically significant at 5 and $1 \%$ respectively which implies that fisherfolks without improved fishing gears and employ manual outboard such as paddle tend to have an array of livelihood sources and their distribution is more uneven. The availability of modern fishing gears enable the fisherfolks to rely more on actual fishing and exploit distance fishery resources which invariably increase their income. In remote areas there are no income possibilities outside selfemployment within agriculture.

Conversely, the coefficients of household size $(0.008)$ and per capita expenditure $(0.306)$ were 
positive and statistically significant at 1 and $5 \%$ level of probability respectively.

This suggests that fisherfolks with large family size tend to diversify more to cater for the member of household and improve their per capita expenditure. This result is consistent with several studies: Schwarze and Zeller, (2005), Oladimeji et al. (2015), Femi and Adelomo, (2016), Oladimeji, (2018), that fisherfolks with large household size and dependents have likelihood to engage in supplementary earnings aside their main occupation. This could be for either consumption or to foster education of their wards and family health care or to minimize income fluctuation or shocks as experienced by the sampled fisherfolks. In addition, credit had significant positive effect on livelihood diversification of the sampled fisherfolks in line with Schwarze and Zeller, (2005) and Oladimeji, (2018) suggesting that better-off households through credit diversify more out of the fishery sector than less privilege ones. Credit seems to enable household members to extend their participation to fishery and new activities.

\section{Impact of Shiroro dam project on the livelihood diversification of fisherfolks}

The result of impact of Shiroro dam on the income accrued to fisherfolks was achieved through t-test as depict in Table 3. The result showed that the mean income of fisherfolks who benefitted from Shiroro dam project ( $\$ 56,119.06$ per annum) for fisheries activities is greater than that of counterfactual (\$37,876.80). The t-statistics was statistically significant at $1 \%$ which implies that there is a significant difference between the accrued incomes of fisherfolks that participated in fishing enterprise compared to non-participants. Therefore it can be concluded that the Shiroro dam project impact on the livelihood of fisherfolks.

Table 3. t-test of the impact of the Shiroro dam project on the fisherfolks' income

\begin{tabular}{lll}
\hline Variables & Beneficiaries & Non-beneficiaries \\
\hline Mean $(\mathrm{N})$ & $56,119.062$ & $37,876.800$ \\
Variance & 39.0085 & 45.752 \\
Observation & 363 & 267 \\
Hypothesized mean difference & 0 & \\
Df & 628 & \\
$\mathrm{t}-\mathrm{statistics}$ & $5.770081^{* * *}$ & \\
$\mathrm{P}(\mathrm{T} \leq \mathrm{t})$ one tail & $0.200827 \mathrm{E}-03$ & \\
$\mathrm{t}$ critical one tail & 1.8608275 & \\
$\mathrm{P}(\mathrm{T} \leq \mathrm{T})$ two tail & $0.4973341 \mathrm{E}-04$ & \\
$\mathrm{t}$ critical two tail & 2.28342 & \\
\hline
\end{tabular}

*** denote statistically Significant at $1 \%$

Impact of Shiroro dam on Productivity of fisherfolks

The impact of Shiroro dam on fisherfolks' productivity was achieved through Propensity Score Matching (PSM) and Local Average Treatment Effect (LATE) model. The two analytical tools concurrently tackled the problem of selection bias and particularly non-compliance or problem of endogeneity.

Table 4: Comparison between NN, R and K algorithms

\begin{tabular}{|c|c|c|c|}
\hline Algorithms by matching & T-value & Rubin's B & Rubin's R \\
\hline Nearest neighbor $(\mathrm{NN})$ & $2.62 * * *$ & 12.83 & 1.08 \\
\hline Radius (R) & $2.03 * *$ & 21.7 & 1.09 \\
\hline Kernel (K) & $2.00 * *$ & 23.00 & 1.29 \\
\hline \multicolumn{4}{|l|}{ PSM Diagnostic statistics } \\
\hline Observation & 630 & & \\
\hline Mean & 0.549 & & \\
\hline Standard deviation & 0.251 & & \\
\hline Minimum & 0.0091 & & \\
\hline Maximum & 1.0000 & & \\
\hline
\end{tabular}

For propensity score, nearest neighbor (NN) matching algorithm was used to match the socioeconomic characteristics between beneficiary and non-beneficiaries fisherfolks based on the t-value, Rubin B and Rubin R in Table 4. NN also uses the propensity score of individuals alike in the treated and control group to construct the counterfactual outcome with its major advantage of having lower variance which is achieved because more information is used.

Propensity scores were obtained through Logit regression model and fisherfolks involved in the Shiroro dam were matched on the basis of the proximity of their propensity scores of participating 
to fisherfolks in the counterfactual using individual socio-economic characteristics to form matched pairs of observational similar individual characteristics (Table 5). All other fisherfolks whose propensity scores for involvement in Shiroro dam fishing were different from the range of scores for the Shiroro fisherfolks were dropped from the analysis. The propensity score is a probability, so the average probability in the treatment for fisherfolks was 0.549 .

The results of the impact of Shiroro dam on productivity of fisherfolks are presented in Table 6.
The result revealed that the average output per unit of inputs of the Shiroro fisherfolks was $6.0320 \mathrm{~kg}$. This implies increasing return to scale, a unit increase in their inputs will lead to 6.032 units increase in the fish harvest. This result seems to be on high side simply because most fisherfolks committed little investment into artisanal fishery and take advantage of the opportunity of the dam for higher harvest. Therefore, the average impact estimation shows that involvement in Shiroro dam had a significant and positive impact on productivity of the fisherfolks.

Table 5: Maximum likelihood estimates of the propensity score for Shiroro dam

\begin{tabular}{lccccc}
\hline Variable & $\beta$ & SE & T-value & P > /Z/ & Marginal effect \\
\hline Constant & $-1.087^{* * *}$ & -0.359 & -3.03 & 0.000 & 0.0965 \\
Age & $0.321^{*}$ & 0.164 & 1.96 & 0.059 & 0.0063 \\
Marital status & 0.087 & 0.105 & 0.83 & 0.521 & 0.0732 \\
Household size & $-0.390^{* *}$ & 0.188 & -2.08 & 0.036 & -04210 \\
Cooperative & 0.457 & 0.427 & 1.07 & 0.347 & 0.127 \\
Education & 0.521 & 0.521 & 1.00 & 0.357 & 0.0086 \\
Credit & $-0.076^{* * *}$ & 0.019 & -3.91 & 0.000 & -0.07231 \\
LGA (dummy) & $0.342^{*}$ & 0.195 & 1.75 & 0.072 & 0.214 \\
LR Chi ${ }^{2}$ (7) & 73.09 & & & & \\
Prob $>$ chi & 0.000 & & & & \\
Pseudo R & 0.324 & & & & \\
Wald test & 0.087 & & & & \\
Observations & 630 & & & & \\
\hline
\end{tabular}

Note: $* * * \mathrm{P}<0.01$ and $* *<0.05$ levels of probability.

Table 6: Impact of Shiroro dam on fisherfolks' productivity

\begin{tabular}{lllllrr}
\hline Estimation by & Sample & Treated & Control & $\beta$ & SE & T-value \\
\hline Output-input ratio & Unmatched & 6.0320 & 5.7002 & $0.3318^{* * *}$ & 0.0987 & 3.36 \\
& ATT & 7.9725 & 5.1452 & $2.8273^{* * *}$ & 0.8754 & 3.23 \\
& ATU & 3.4290 & 3.3008 & $0.1282^{* *}$ & 0.0562 & 2.28 \\
& ATE & & & 0.6654 & & 0.1965 \\
WALD Chi ${ }^{2}$ test & & & & 0.50821 & 0.0976 & 19.91 \\
Participant versus & & & 1.9432 & 0.406 & 2.54 \\
Non-participant & & & 0.0332 & 0.3908 & 2.33 \\
Observed diff. & & & & 0.9102 & \\
\hline
\end{tabular}

Note: treated $=$ beneficiaries and control $=$ non-beneficiaries, Note: $* * * \mathrm{P}<0.01$ and $* *<0.05$ levels of probability.

The Treatment Effect on the Treated (ATT) on the average also had a positive impact and increases productivity of the benefitted fisherfolks by 2.8273 $(38.1 \%)$. This implies that Shiroro dam project positively impacted on the participants' productivity. The Treatment Effect on the Untreated (ATU) was estimated by matching a similar treated fisherfolks to each non-treated respondent. The result showed that ATU had a significant and positive (0.1282) impact on productivity, this is the counter factual outcome of the treated had it been they were not treated. The Average Effect of the Treatment (ATE) for Shiroro dam fisherfolks has a positive difference of 0.6654 compared to the treated category. The positive impact of Shiroro dam on fisherfolks' income and productivity is similar to the finding of Idi et al. (2019) on micro-credit utilization and its impact on famers maize output and household food security in Kaduna state, Nigeria.

The LATE estimate was carried out for productivity using WALD chi square estimator proposed by Imbens and Angrist (1994) and adopted by Heckman and Hotz, (1989), Hünermund and Czarnitzki, (2016). For the productivity, the result of its LATE mean difference as shown in Table 6 is that there was a significant difference of 0.9102 in fishery productivity between the beneficiaries and non-beneficiaries. This implies that the productivity of the participants of Shiroro dam fisherfolks were 
0.9102 units higher when compare with the nonbeneficiary's counterpart. Therefore, the LATE estimate analysis showed that Shiroro dam significantly and positively increase fisherfolks productivity by 0.50821 units. This is the average change in productivity brought about by the participation in Shiroro dam fisherfolks. LATE model does not over-estimate or under-estimate the impact of a project because of its ability to estimate the impact of project in a situation of noncompliance and ability to bring out the actual impact of the project irrespective of other factors that might influence the outcome of interest.

The hypothesis which stated that Shiroro dam utilization has no impact on fish caught of the beneficiaries in the study area was conducted using T-test (Table 7). Fisherfolks output involved in Shiroro dam utilization after nearest neighbor matching was $32,980.07 \mathrm{~kg}$ while that of fisherfolks who were not involved in the dam utilization was $27,004.05 \mathrm{~kg}$. Consequently, the impact of Shiroro dam utilization on fish harvest (ATT) was 5,976.02 $\mathrm{kg}$. This was statistically significant at $1 \%$ level of probability. This implies that the null hypothesis which state that Shiroro dam utilization has no impact on fish harvest of the beneficiaries in the study area was rejected at $1 \%$ level of probability. In other words, there is a significant impact of Shiroro dam utilization on fish output of the beneficiaries in the study area.

Table 7. T-test of the impact of Shiroro dam accessibility on productivity of fisherfolks

\begin{tabular}{llllll}
\hline Variables & Treated & Control & ATT & SE & T-statistics \\
\hline Fish caught $(\mathrm{kg})$ & $32,980.07$ & $27,004.05$ & $5,976.02$ & 901.41 & $3.00^{* * *}$ \\
\hline
\end{tabular}

Source: Author's estimates, Note: $* *<0.01$, ATT=Average Treatment Effect on the Treated (Impact)

The results of perception on constraints encountered by Shiroro dam fisherfolks presented in Table 8 indicates that inaccessibility of credit was perceived as the most critical with mean of 3.29. High cost of fish equipment (3.22), highest cost of hired labour (3.01) and Inadequate storage facilities $(X=3.22)$ were also critical constraints hindering fishery practices in the study area. The result corroborates the study of Oladimeji et al. (2013) on empirical analysis of artisanal fishery practices and constraints in North Central, Nigeria.

Table 8. Perception on severity of constraints encountered by Shiroro dam fisherfolks

\begin{tabular}{llllllll}
\hline Component & VH & H & L & N & WS & MS & Rank \\
\hline inaccessibility of credit & 852 & 228 & 80 & 34 & 1194 & 3.29 & $1^{\text {st }}$ \\
high cost of fish equipment & 792 & 237 & 108 & 32 & 1169 & 3.22 & $2^{\text {nd }}$ \\
high cost of hired labour & 668 & 255 & 116 & 53 & 1092 & 3.01 & $3^{\text {rd }}$ \\
inadequate storage facilities & 348 & 555 & 104 & 39 & 1046 & 2.88 & $4^{\text {th }}$ \\
distance of markets & 364 & 144 & 264 & 92 & 864 & 2.38 & $5^{\text {th }}$ \\
accessibility to fuel & 180 & 228 & 354 & 65 & 827 & 2.29 & $6^{\text {th }}$ \\
infestation by hyacinth & 168 & 135 & 156 & 197 & 656 & 1.81 & $7^{\text {th }}$ \\
climatic variability & 216 & 66 & 84 & 245 & 611 & 1.68 & $8^{\text {th }}$ \\
\hline
\end{tabular}

$\mathrm{VH}=$ very high, $\mathrm{H}=$ high, $\mathrm{L}=$ low, $\mathrm{N}=$ not at all, $\mathrm{WS}=$ Weighted score, $\mathrm{MS}=$ mean score, $\% \mathrm{MS}=$ percentage mean score

\section{CONCLUSION}

The study revealed that income from fishery was the most important source of income for fisherfolks in the study area. The key determinants of livelihood diversification among fisherfolks were the length of fishing gears, capacity of outboard engine, household size, credit accessed for fishery and per capita expenditure. Therefore, income from both artisanal fishery and non-farm could be combined to minimize income stress, fluctuation and shocks.

Fisherfolks should form a formidable social organization to benefit from economy of bulk purchase of farm inputs especially fishing gears and outboard engine, farm advisory services, increased access to credit, and access to other modern fishing techniques.

\section{REFERENCES}

Abayomi, K. I., Murtala, A. I., Babatunde, O. and Suleiman, A. (2015). Trend analysis of hydro-meteorological data for river Kaduna at Shiroro dam site, Niger State. Journal of Scientific Research and Reports, 8(5), 1-12.

Bashir, A. and Kyung-Sook, C. (2018): A review of the evaluation of irrigation practice in Nigeria: Past, present and future prospects. Journal of Agricultural research, 13(40), 2087-2097.

Barrett, C. B., Reardon, T. and Webb, P. (2001). Non-farm income diversification and household livelihood strategies in rural 
Africa: concepts, dynamics, and policy implications. Food Policy, 26(4), 315-331.

Bernard, A. S. A., Samuel, A. and Edward E. O. (2014). Determinants of income diversification of farm housholds in the western region of Ghana. Quarterly Journal of International Agriculture, 53(1), 55-72.

Femi, M. O. and Adelomo B. S. (2016). Farm households' income sources diversification behavior in Nigeria. Journal of Natural Sciences Research, 6(4), 102-111.

FAO (2012). The state of world fisheries and aquaculture 2010 \&2018. Food and Agricultural Organisation of the United Nations, Rome, Italy.

Heckman, J. J. and Hotz, V. J. (1989). Choosing among alternative non-experimental methods for estimating the impact of social programs: the case of manpower training. Journal of the American Statistical Association, 84(408), 862-874.

Heckman, J., Ichimura, H. and Todd, P. (1997). Matching as an Econometric Evaluation Estimator: Evidence from Evaluating a Job Training Program," Review of Economic Studies, 64, 605(654).

Hunermund, P. and Czarnitzki, D. (2016). Estimating the Local Average Treatment Effect of R\&D Subsidies in a Pan-European Program. Discussion Paper No. 16-039, 42PP.

Idi, A. S. Damisa, M. A., Ahmed, B., Edekhogregor, O. I. and Oladimeji, Y. U. (2019). Macrocredit utilization and as impact on farmers maize output and household food security in Kaduna State, Nigeria. Journal of Agric. and Environment, 15(1),19-31.

Imbens, G. W. and Angrist J. D. (1994). Identification and estimation of local average treatment effects. Econometrica, 62(2), 467-476.

International Council for Science (ICSU) / the International Social Science Council (ISSC), (2015). Review of targets for the sustainable development goals: The science perspective. A report. 92pp.

Kolo, A. I. (1996). The assessment of physicchemical parameters of Shiroro Lake and its major tributaries.
Oladimeji, Y. U., Abdulsalam, Z., Damisa, M. A., Ajao, A. M. and Sidi, A. G. (2013). Empirical analysis of artisanal fishery practices and constraints: a synergy to poverty alleviation and sustainable fishery development in north central, Nigeria. Ethiopia Journal of Applied Science and Technology, 4(2), 85 - 102.

Oladimejl, Y. U. and Abdulsalam, Z. (2015). Determinants of participation of rural farm households in non-farm activities in Kwara State, Nigeria: a paradigm of poverty alleviation. Ethiopian Journal of Env Studies and Management, 8(6), 635 - 649.

Oladimeji, Y. U., Abdulsalam, Z., MuhammedLawal, A., Adefalu, L. L., Adepoju, S. A. (2016). Economic analysis and effects of water hyacinth (Eichhornia crassipes) on artisanal fishery of river Niger in northcentral Nigeria. Journal of Animal Production Research, 28(2), 338-349.

Oladimeji, Y. U. (2018). Effect of livelihood diversification strategies among rural artisanal fisherfolks in north-central and north-western Nigeria. African Journal of Agriculture Technology and Environment, 8(1), 1-15.

Philip, H., Brown, A., Desiree, T. B., Bryan, T. C., Darrin, M. D., Aaron, T. and Wolf, E. (2008). Modeling the costs and benefits of dam construction from a multidisciplinary perspective. Journal of Environmental Management, 1-8.

Readon, T. (1997).Using evidence of household of income diversification to inform study of rural non-farm labour market in African: World Development, Vol 25, No: 735-47. Resettlement in the Narmada Valley. New Delhi: Oxford University Press.

Rosenbaum, P. R. and Rubin, D. B. (1983). The central role of the propensity score in observational studies for causal effects. Biometrika, 70(1), 41-55.

Schwarze, S. and. Zeller, M. (2005). Income diversification of rural households in central Sulawesi, Indonesia. Quarterly Journal of International Agriculture, 44(1), 61-73.

Skinner, J., Niasse, M. and Haas, L. (2009). Sharing the benefits of large dams in West Africa. natural resource issues No. 19. International Institute for Environment a Development, London, UK. 
Usman, A. and Ifabiyi, I. (2012). Socio-economic analysis of the operational impacts of shiroro hydropower generation in the lowland.

The World commission on Dams, WCD, (2000). Dams and development: a new framework for decision-making. A report, Eathscan publications Ltd, London and Sterling, VA pp. 404. Available at www.dams.org/ report.
Philip, H., Brown, A., Desiree, T. B., Bryan, T. C. Darrin, M. D., Aaron, T. and Wolf, E. (2008). Modeling the costs and benefits of dam construction from a multidisciplinary perspective. Journal of Environmental Management, 1-8. 